\title{
Modernity and ecology in the aspect of a packaging industry company management
}

\author{
Agnieszka Ociepka-Kubicka ${ }^{1, *}$ \\ ${ }^{1}$ Czestochowa University of Technology, Faculty of Management, Armii Krajowej 19B, \\ 42-200 Częstochowa, Poland
}

\begin{abstract}
The article discusses the issue of innovativeness in the area of packaging with reference to the balanced development. It also presents the threats of the packaging industry to the natural environment and the methods and tools of their restriction. The importance of biodegradable packaging and packaging from recycled materials is stressed. Moreover, the problems of the burdensomeness of packaging products and the packaging manufacturers are emphasised. Modern enterprises must implement pro-ecological, innovative activities, both at the level of production and the company's management. The changing economic conditions and the social pressure result in the new company's management goals - alongside the production, financial and other aspects. These new goals refer to the widely understood environment, and human life and health. The analysis of the innovative and pro-ecological activities implementation was presented on the example of a modern, dynamically developing joint stock company, United Packaging S.A., producing packaging from corrugated board with the increased water resistance for food industry, household chemicals and electronic industry.
\end{abstract}

\section{Introduction}

The world packaging market, according to forecasts in the coming years, will develop very dynamically. At present, the packaging fulfils numerous functions such as storage and protection against pollution or damage, transportation, distribution and product advertising. Research by an international consultancy company, Smithers Pira, shows that by 2020 the world's packaging sector will grow by $3.5 \%$ per year, to reach 1 trillion US dollars in that year. According to the Polish Chamber of Packaging (PIO) forecasts, with a 4-5\% growth rate of the Polish packaging market by 2020, it will reach a comparable level with the developed markets of Western Europe. Polish industry meets domestic needs and 15-20\% of its output is directed at the foreign markets. Taking environmental issues into consideration in the rapidly growing packaging industry is one of its major challenges [1]. Extensive data presented in the Report indicate the world-wide tendencies to the increasing application of ecological packaging, in order to minimise the negative impact on the environment. Research show that the region in the Report referred to as Asia-Pacific, will become the leader of the ecological packaging market. It is expected that North America and Western and Eastern

* Corresponding author: agnieszkaociepa22@wp.pl 
Europe will have a substantial deal in the ecological packaging market thanks to their rigorous governments' environment politics. Research show also that Japan will have higher and higher position on the ecological market due to its highest use per capita [2]. In the packaging process, both traditional and - more and more frequently - new raw materials, subsidiary materials and technologies are used. This evokes the waste generation, discharge of sewage into water and/or earth, and dust and gases into the atmosphere. Also the management of the packaging waste constitutes a problem. The article discusses the innovation issues in the packaging industry in terms of sustainability. The work consists of two parts. The purpose of the first part is to identify the environmental risks associated with the packaging industry and the possibilities of their reduction. The second part presents the modern, dynamically developing company, United Packaging S.A., which produces corrugated cardboard packaging with increased hydro resistance for the food industry, household chemistry and the electronics industry.

\section{Innovation in the packaging industry and sustainable development}

Packaging is one of the most important processes without which nowadays products would not be finished. Observing the principles of sustainable development, which proclaim the need of reconciliation of the economic development with the social expectations and the protection of the environment, is increasingly perceived as necessary. This awareness poses a difficult challenge for companies, as they have to follow the market requirements of their customers while taking into account the environmental requirements [3]. In addition, demographic and lifestyle changes, related among others to the aging of society, force the production of qualitatively innovative packaging. The ecological aspect of packaging must be taken into account not only at the manufacturing stage, but also for the use and disposal of packaging [4].

Table 1. Structure of the packaging market in Poland and Europe from the packaging material type point of view, 2020 (own study based on [5])

\begin{tabular}{|c|c|c|}
\hline \multirow{2}{*}{ Fabric } & \multicolumn{2}{|c|}{ Market share [\%] } \\
\cline { 2 - 3 } & Poland & Europe \\
\hline Plastics & 38.0 & 38.0 \\
\hline Paper and cardboard & 36.2 & 38.5 \\
\hline Metal & 10.0 & 8.0 \\
\hline Glass & 8.2 & 7.5 \\
\hline Wood and others & 7.6 & 8.0 \\
\hline
\end{tabular}

It should be emphasized that the introduction of new packaging to the market should be based on a comprehensive analysis of its impact on the environment at different stages of the life cycle. The impact of the packaging on the environment depends on the: design, sourcing, production, distribution, use and recycling. Research indicates that the packaging industry can be a serious threat to the natural environment, inter alia due to the:

- possibility of harmful substances' emissions into the atmosphere, soil and water during the production process,

- possibility of environmental pollution during the packaging waste deposition in landfills,

- potential presence in packaging materials of heavy metals such as lead, cadmium, mercury, chromium and other harmful substances that may be hazardous to health and life,

- environmental impact of packaging and packaging waste from the production and distribution, resulting from the lack of use of various methods of their disposal. 
According to the report of DNB Bank Polska: "Packaging. Industry Report, 2017", the world packaging market is going to grow dynamically (around 6\% in 2018) and to a great extent is dependent on the material used in the packaging production. The report characterises the packaging materials and presents the anticipated growth of particular packaging types in 2018.

Table 2. Anticipated growth of packaging sectors in 2018 on the basis of DNB Report (own study based on [5])

\begin{tabular}{|c|l|c|}
\hline $\begin{array}{c}\text { Packaging } \\
\text { material }\end{array}$ & \multicolumn{1}{|c|}{ Short characteristics } & $\begin{array}{c}\text { Growth in } \\
2018\end{array}$ \\
\hline Paper & $\begin{array}{l}\text { The raw material is widely available, lightweight, paper packaging } \\
\text { production is cheap, easily processed, printable, biodegradable and } \\
\text { environmentally friendly. Its disadvantage is soaking which reduces the } \\
\text { mechanical durability }\end{array}$ & $2 \%$ \\
\hline Glass & $\begin{array}{l}\text { Very good properties for storing food and beverages (it is sterile and does } \\
\text { not absorb moisture), in addition, similarly to paper, it is 100\% } \\
\text { recyclable. The disadvantage is often the need to additionally use } \\
\text { protective packaging }\end{array}$ & $3 \%$ \\
\hline Metal & $\begin{array}{l}\text { Mechanically strong, with adequate hardness which facilitates transport, } \\
\text { higher packaging production costs as compared to paper, not as ductile } \\
\text { as, for example, plastic. The disadvantage is its high thermal } \\
\text { conductivity }\end{array}$ & $5 \%$ \\
\hline Plastic & $\begin{array}{l}\text { It is light, durable, sterile, suitable for long-time food storage. Plastic is } \\
\text { not biodegradable, it is the environment-polluting waste, its recycling is } \\
\text { difficult and expensive }\end{array}$ & $9-10 \%$ \\
\hline
\end{tabular}

Although the plastic is not biodegradable, is a waste polluting the environment and its recycling is difficult and costly, the greatest increase in packaging production is forecasted for plastic packaging (9-10 per annum). The use of plastic packaging is primarily determined by economic and practical factors. On the other hand, taking into account that the average time of decomposition of a plastic bottle is up to 450 years, recycling of such packaging becomes a serious challenge and a major risk for their development. For instance, France has introduced a law stating that by 2020 disposable plates and cutlery should only be made of biodegradable materials. The European Union plans to reduce the number of disposable bags by $80 \%$ within 15 years.

\subsection{Possibilities to limit the negative impact of packaging on the environment}

Packages must meet numerous requirements, e.g. technical, promotional, informative, ecological and economic, to fulfil their functions properly. Each one is important, but environmental requirements are, more and more frequently, playing a substantial role. According to estimates, annually we generate about 530 thousand tons of used paper and cardboard packaging, 466 thousand tons of glass packaging, 276 thousand tons of plastic packaging and laminates, as well as 130 thousand tons of metal packaging. The weight of used packaging that affects the environment per year per one inhabitant of Poland equals approximately $70 \mathrm{~kg}$ and is still much lower than in Western Europe. The world average is around $150 \mathrm{~kg}$. In terms of value in the above-mentioned countries, the use of packaging per capita varies between EUR 300-340, with approximately EUR 212 in Poland. The packaging market in Poland is systematically growing. According to the forecast of the Polish Chamber of Packaging, with approximately 4-5\% pace of economic development in 2014-2020, it will reach a comparable level with the markets of Western European countries. In accordance with the principles of sustainable development, the production of packaging should not cause negative changes in the environment. In order to achieve this principal goal the packaging industry should: be based on renewable natural resources, protect ecosystems, biodiversity, 
minimize harmful emissions. The packaging waste management is also a serious problem. In accordance with the waste management principles of the EU Waste Framework Directive (2008/98/EC), waste prevention is the primary priority in the waste management. The Directive of the European Parliament and of the Council on packaging and packaging waste (94/62/EC, as amended by Directive 2004/12/EC), also contains provisions for the prevention of packaging waste, especially those deposited in landfills. Under these rules, the re-use of packaging and the recovery and recycling of packaging waste is undoubtedly a good means of preventing waste. Research shows that consumers much more willingly purchase products in natural, ecological packaging [6]. In addition, modern food packaging is expected to extend the shelf life of the product. Advances in new food packaging technologies include delaying oxidation, preventing microbial development, preventing moisture, etc. New food packaging technologies beyond the primary function must increase the safety of storage and transport of food.[7]Therefore, when designing a new packaging, in order to reduce the burden on the environment, the following aspects are important: the production of reusable packaging, the manufacture of packaging materials from recyclable materials, the use of natural-origin materials in the production of packaging, the use of smaller quantities of materials for the packaging production, the production of packaging free from pollution, e.g. with heavy metals. At the design and production stage, what also should be taken into account is the following: the emission of gases from the production processes, greenhouse effect, the energy consumption of the production, the adaptation of packages to the requirements of their biodegradation, the adaptation of packages to the requirements of incineration of packaging waste with energy recovery. Recycling as the process of the waste materials reprocessing, for economic reasons, as well as environmental protection, is a very desirable solution. Recycling of packaging is of great importance in the recovery of metals, glass, waste paper and certain plastics. Organic recycling is the oxygen or anaerobic treatment of biodegradable packaging waste. This recycling is used for packages made of biodegradable polymers, e.g. synthetic polyesters or the ones of microbial origin, starch and cellulose. Waste generated from ecological packaging, as opposed to the plastic waste, is biodegraded. Therefore, this type of packaging is considered the most environmentally friendly. The materials based on paper are the most recyclable materials in the world: the paper and cardboard recycling level equals $70-80 \%$ in North America, and even $90 \%$ in Central Europe. Another way of re-using paper packaging is degradation (biodegradation, compost). Packaging may be considered as biodegradable if it is made from organic substances, such as cellulose or synthetic compounds, which may be easily decomposed by natural bacterial or fungal processes. The cellulose packaging biodegradation level depends on the substances used in the production process and on other materials used as surface treatment [6]. According to the European Standard EN 13432:2002, a biodegradable material should degrade at least 90\%in 6 months, in an environment rich in carbon dioxide (UNI EN 13432:2002). On the other hand, according to the UNI EN 14995:2006, a material is "compostable" if it degrades at least $90 \% \mathrm{n}$ biodegradable fragments of the dimension of $2 \mathrm{~mm}$, in contact with organic materials in a period of 3 months (UNI EN 14995:2006) [8, 9]. In spite of the vast activities in the field, many authors underline that the recycling of - among others - packaging waste, is insufficient and still remains a global issue [10]. Analysing the packaging life cycle, the total greenhouse gas index is considered, produced directly and indirectly at the various stages of the product life cycle, which is referred to as the carbon footprint. Taking into account the packaging material production stage, the materials derived from plant materials are more advantageous in terms of $\mathrm{CO}_{2}$ emissions. This is due to the fact that plants assimilate $\mathrm{CO}_{2}$ during photosynthesis. An example is a fully biodegradable polymer, such as polylactide. It is obtained from renewable raw materials such as maize. Another example is the use of synthetic petroleum based polymers for the production of packaging [11]. In the packaging industry, rapidly growing innovation is observed. Research is being done around the world 
to use smaller quantities of packaging materials and renewable sources [12]. More and more often, new composite materials based on natural fibers of plant origin, such as coconut, reed, wheat straw etc., are used for production [13-15]. Design labels sensitive to the changes in the internal state of the package, which changes through a visible colour, will alert the consumer about the freshness or reaching the expiry date of the product [16]. In order to minimize the impact on the environment, printing ink is improved. Water-based printing ink, containing no toxic chemicals is preferred. Research on methods and measures to prevent the migration of harmful substances in the form of sorption coatings, in packaging materials of cellulose origin has been carried out.

\section{United Packaging SA as an example of modern and ecological company}

United Packaging S.A is located at Skarbimierz in the Opole Province .The company acts in accordance with the principles of sustainable development. In this way, it approaches the use of natural resources since their only rational use leads to the natural environment protection. It also attains a positive effect on the natural environment through many actions, such as increasing the share of renewable energy sources, reducing the material consumption of production, as well as in the area of waste, water and sewage management. A solar farm of an area of approx. $700 \mathrm{~m}^{2}$ has been built on the premises of the Production Plant, which consists of 290 VITOSOL 200-F SV2-type high-performance flat collectors supplied by Viessmann, along with a heat accumulation unit, a heat distribution unit and an emergency cool-down unit. The total annual heat yield by the solar farm resulting from the local insolation and the optical efficiency of the installed solar collectors exceeds $690 \mathrm{MWh}$. Considering the solar installation's thermal losses that have a considerable influence on the overall performance of the system, it can be stated that the Skarbimierz Solar Farm allows an annual saving of about $43.000 \mathrm{~m}^{3}$ of gas. The total annual reduction of $\mathrm{CO}_{2}$ emission exceeds 80 tons. The Company utilizes solar energy for heating up the production and storage and the welfare and office areas. Another action undertaken by the company within the framework of ecological activity is the reduction of the production material consumption by cutting down the raw material losses in the corrugated cardboard printing process. Moreover, a digital Quality Control System implemented in the corrugated cardboard printing technological line has reduced the initial loss level by another $30 \%$. These losses are reduced by setting the individual colours of the print relative to one another and controlling the process in an automatic manner by a digital camera system. Reduction of the washing water consumption level is another pro-ecological action undertaken by the Company. It makes it possible to save the water, generate less waste water, so the expenditures incurred for the purchase and commissioning of this innovative (Eco-drive) system are paying off. The Company's "by-product" is waste water containing residues of paints that significantly affect the natural environment; therefore, we have also invested in the construction of the Company's mechanical and biological waste treatment plant. These are major pro-ecological projects that will also yield specific economic effects. The Company has a functioning Environmental Management System complying with the ISO 14001 standard. In addition, it has a Quality Management System in place complying with the ISO 9001 and BRC IOP standards for companies manufacturing packaging intended for contact with food.

\subsection{The Company's innovative activity}

From the outset, the Company has been focusing on innovation. As a matter of fact, it is constantly looking for state-of-the-art solutions it could implement. Such modern 
technologies are often linked with pro-ecological solutions. It has been searching for solutions which, on the one hand, would modernize and speed up the production process and, on the other hand, would initiate environmental protection activities. Research and development processes have been launched that encompass both the materials technology, and the unique design supporting the function of protecting products against moisture. In addition, by equipping the printing line with the innovative Eco-drive system, it is possible to reuse the last washing-stage water for pre-washing of the printing units in the next production cycle, as well as to use the digital Quality Control System in the corrugate cardboard printing technological line.

\section{Conclusion}

Fast expansion entails an increasing influence of businesses on the natural environment. Modern companies should be managed in a strategic, market-oriented and innovative manner. The world packaging market has been developing rapidly and the necessity of ecological packaging has been increasing. For their products to be competitive, they must care for the product quality, which in turn requires them to be open to change. Implementing ecological solutions in the packaging industry on a wide scale may help in reducing many key environmental problems, which include primarily the unfavourable climate change, the depletion of natural resources, the environmental pollution or the loss of biodiversity. Therefore, the success of a company in the contemporary economy is more and more often assessed from the ecoinnovation point of view. Ecoinnovative technologies or products enable a company to compete in the market, which is the indicator of its success. For this reason, managing modern companies must be based on thorough knowledge and competences that enable the creation of innovative solutions. A good example is the dynamically growing United Packaging SA company that manufactures corrugated cardboard packaging of enhanced hydro-resistance.

\section{References}

1. Koskela S., Dahlbo H., Judl J., Korhonen M.R., Niininen M. Reusable plastic crate or recyclable cardboard box? A comparison of two delivery systems. Journal of Cleaner Production, 69, pp 83-90, (2014)

2. https://www.transparencymarketresearch.com/ecological-packaging-market.html (20.04.2018)

3. Heide M., Olsen S. Influence of packaging attributes on consumer evaluation of fresh cod. Food Quality and Preference, 60, pp 9-18, (2017)

4. Wikström F., Williams H., Verghese K. Clune S. The influence of packaging attributes on consumer behaviour in food-packaging life cycle assessment studies - a neglected topic. Journal of Cleaner Production, 73, pp 100-108, (2014)

5. Wasiak W., Przemysł i rynek opakowań w Polsce [Polish Packaging Industry and Market]. Opakowania [Packaging], pp 18-21, (2014)

6. Grundey D. Functionality of Product Packaging: Surveying Consumers' Attitude Towards Selected Cosmetic Brands. Economics \& Sociology, 3, pp 87-103, (2010)

7. Majid I., Nayik G., Dar S.M.,Nanda V. Novel food packaging technologies: Innovations and future prospective. Journal of the Saudi Society of Agricultural Sciences. https://doi.org/10.1016/j.jssas.2016.11.003, (2016)

8. Piselli A., Garbagnoli P., Alfieri I., Lorenzi A., Del Curto B. Natural based coatings for food paper packaging. International Journal of Design Sciences and Technology, 20, pp 55-78, (2014) 
9. Garbagnoli P., Altomare L., Nardo L.,Curto B. Development of active packaging for agricultural food. International Journal of Design Sciences and Technology, 20, pp-79-95, (2014)

10. Tencati A., Pogutz S., Moda B., Brambilla M., Cacia C. Prevention policies addressing packaging and packaging waste: Some emerging trends. Waste Management, 56, pp-35-45, (2016)

11. Liua B., Xu H. Preparation and characterization of intelligent starch/PVA films for simultaneous colorimetric indicator and antimicrobial activity for food packaging applications. Carbohydrate Polymers, 157, pp 842-849, (2017)

12. Krepker M., Shemesh R. Active food packaging films with synergistic antimicrobial activity. Food Control, 76, pp 117-126, (2017)

13. PatríciaRomani V., Prentice-Hernández C. Active and sustainable materials from rice starch, fish protein and oregano essential oil for food packaging. Industrial Crops and Products, 97, pp 268-274, (2017)

14. Pogrell H., Market development of bioplastics and latest biopackaging trends, $4^{\text {th }}$-Conference The future of biodegradable packaging, Warsaw, (2011)

15. Da Cruz N.F., Simões P., Marques R.C. Costs and benefits of packaging waste recycling systems. Resources, Conservation and Recycling, 85, pp 1-4, (2014)

16. Lee S., Yam K. L., Piergiovanni L. Food packaging science and technology. CRC Press, London (2008) 